\title{
Integrating ecosystem services in landscape planning: requirements, approaches, and impacts
}

\author{
Christian Albert • James Aronson • \\ Christine Fürst $\cdot$ Paul Opdam
}

Received: 7 August 2014/Accepted: 13 August 2014/Published online: 10 September 2014

(C) Springer Science+Business Media Dordrecht 2014

\begin{abstract}
Despite growing knowledge of ecosystem services (ES), and heightened awareness of their political and socio-economic relevance, mainstreaming and implementing ES in landscape planning and decision-making are still in their infancy. The objective of this special issue, therefore, is to explore requirements for, approaches to, and potential impacts of, integrating ES in landscape planning and management. The issue includes three key research themes: (i) Requirements and interests of planners and decision-makers for integrating ES in different application contexts, (ii) Approaches to applying ES in (participatory) planning, and (iii) Potential impacts of
\end{abstract}

C. Albert $(\square)$

Institute of Environmental Planning, Leibniz Universität Hannover, Herrenhäuser Str. 2, 30419 Hannover,

Germany

e-mail: albert@umwelt.uni-hannover.de

C. Albert

Department Environmental Politics, Helmholtz Centre for Environmental Research - UFZ, Permoserstraße 15,

04318 Leipzig, Germany

J. Aronson

Centre d'Ecologie Fonctionnelle et Evolutive (UMR

5175, CEFE - campus CNRS), 1919, Route de Mende,

34293 Montpellier, France

e-mail: james.aronson@cefe.cnrs.fr

J. Aronson

Missouri Botanical Garden, 4344 Shaw Blvd, St. Louis, MO 63110, USA integrating ES in policy and decision-making. These themes are addressed by 12 papers that refer to case studies in Africa, Australia, and Europe. Four lessons are highlighted: (i) Information on ES is considered useful by many practitioners, but the type, production and communication of ES information need to be adapted to the specific context of a planning case; (ii) A broad range of approaches are available for integrating the ES concept in (participatory) planning with different and complementary contributions to decision-support; (iii) Effectively integrating ES in planning requires careful scoping of the context, objectives and capacities; (iv) Integrating ES in planning can effectively support the co-production of

\section{Fürst}

Department of Ecology and Natural Resources Management, Center for Development Research, University of Bonn, Walter Flex Str. 3, 53113 Bonn, Germany e-mail: cfuerst@uni-bonn.de

P. Opdam

Wageningen University Land Use Planning Group and Alterra Wageningen UR Nature and Society Group, Droevendaalse Steeg 3, 6708PB Wageningen, The Netherlands

e-mail: paul.opdam@wur.nl 
relevant knowledge and the collaboration of diverse actors. A new research field of 'Planning-for-ES Science' is emerging which focuses on, among other issues, the critical evaluation of real-world case studies of applying the ES concept in different fields of practice.

\section{Enhanced relevance of ecosystem services}

Ecosystem and landscape services have become a key issue in science and policy (Burkhard et al. 2012; Bateman et al. 2013; Bastian et al. 2014) and are recognized as an essential part of the emerging landscape sustainability science (Termorshuizen and Opdam 2009; Musacchio 2013; Wu 2013). Research on ecosystem services (ES) has grown dramatically, as reflected in the exponential increase in papers and special issues referring to the subject (e.g. Potschin and Haines-Young 2011; Geneletti 2013; Hubacek and Kronenberg 2013; Alkemade et al. 2014; Haase et al. 2014; Iverson et al. 2014). Further developments of the ES concept and its application were spurred by major international initiatives, including the Millennium Ecosystem Assessment $\left(\mathrm{MA}^{1}\right)$, The Economics of Ecosystems and Biodiversity $\left(\mathrm{TEEB}^{2}\right)$ studies and the recently established Intergovernmental Platform on Biodiversity and Ecosystem Services (IPBES ${ }^{3}$ ). Finally, strong interest in policy is illustrated by international agreements that address ES such as the Aichi Targets of the Convention on Biological Diversity $\left(\mathrm{CBD}^{4}\right)$ and the EU's Biodiversity Strategy. ${ }^{5}$

Despite the growing knowledge base, and heightened awareness of political and socio-economic relevance of ES, actual mainstreaming and implementation of ES in practical planning and decisionmaking are still in their infancy (Daily et al. 2009; de Groot et al. 2010). Many existing tools and approaches for measuring, mapping, and putting values on ES remain to be tested in practice (Cowling et al. 2008; Hauck et al. 2013). In some areas, tools are still lacking. Knowledge and practical knowhow are

\footnotetext{
1 http://www.maweb.org

2 http://www.teebweb.org

3 http://www.ipbes.net

${ }^{4}$ http://www.cbd.int/sp/targets/

5 http://www.ec.europa.eu/environment/nature/biodiversity/ comm2006/2020.htm
}

needed concerning how and when existing or proposed tools can actually support planning practice (Primmer and Furman 2012; Opdam et al. 2013). Conversely, studies are needed as to which information needs and requirements planners and decision-makers have concerning the possible integration of ES information in existing administrative and decision-making structures. This is particularly the case for planning at the landscape scale, which is widely perceived as most useful and relevant for land use decision-making concerning the quality, diversity, flow rates, and distribution of ES (Termorshuizen and Opdam 2009; de Groot et al. 2010; von Haaren and Albert 2011; van Oudenhoven et al. 2012).

\section{Objective and contributions of the special issue}

The objective of this special issue is to explore options and impacts of integrating ES concepts and information in planning to support decision-making for sustainable landscape development. It addresses three key research themes:

1. What are the requirements and interests of planners and decision-makers for integrating the ES concept and ES information in different application contexts?

2. How can the ES concept be applied within existing (or new) planning instruments and participatory planning processes?

3. Which impacts can be expected from integrating the ES concept in policy and decision-making?

The special issue contains 12 papers, each of which addresses one or more of the three research themes, from differing perspectives and with reference to one or more case studies in Europe, Australia, and Africa (Table 1). All selected papers employ participatory approaches involving potential users, develop an approach for actual implementation within existing planning, or explore implications for practice.

\section{Key messages}

ES: a useful concept for planning

Many planners and decision-makers find the ES concept potentially useful, but the type, production 
Table 1 Key research themes and associated contributions

\begin{tabular}{|c|c|c|c|}
\hline Authors & Objectives & Research methods & Case study area \\
\hline \multicolumn{4}{|c|}{$\begin{array}{l}\text { Theme I: What are the requirements and interests of planners and decision-makers for integrating the ES concept and ES information } \\
\text { in different application contexts? }\end{array}$} \\
\hline $\begin{array}{l}\text { Mascarenhas } \\
\text { et al. (2014) }\end{array}$ & $\begin{array}{l}\text { To gain insight on the views and } \\
\text { perceptions of Portuguese regional spatial } \\
\text { planners regarding the ES concept and its } \\
\text { integration in spatial plans }\end{array}$ & $\begin{array}{l}\text { Questionnaire survey aimed at } \\
\text { practitioners and decision-makers from } \\
\text { planning authorities }\end{array}$ & Portugal \\
\hline $\begin{array}{l}\text { Albert et al. } \\
\text { (2014) }\end{array}$ & $\begin{array}{l}\text { To investigate how landscape and regional } \\
\text { planners in Germany already use } \\
\text { environmental information, and explore } \\
\text { their perceptions concerning an } \\
\text { integration of additional information on } \\
\text { ES in their work. }\end{array}$ & $\begin{array}{l}\text { Semi-structured interviews and web-based } \\
\text { survey with German landscape and } \\
\text { regional planners }\end{array}$ & Germany \\
\hline $\begin{array}{l}\text { Sitas et al. } \\
\text { (2014) }\end{array}$ & $\begin{array}{l}\text { To explore options for mainstreaming ES in } \\
\text { development planning at the landscape } \\
\text { scale }\end{array}$ & $\begin{array}{l}\text { Stakeholder engagement process, } \\
\text { interviews, participant observations, } \\
\text { in situ conservations and key documents }\end{array}$ & $\begin{array}{l}\text { Eden district, South } \\
\text { Africa }\end{array}$ \\
\hline
\end{tabular}

Theme II: How can the ES concept be applied within existing (or new) planning instruments and participatory planning processes?

\begin{abstract}
von Haaren To propose a practice-oriented ES
et al. (2014)

evaluation (PRESET) model specifically adapted to the requirements of the local and regional planning and decisionmaking context
\end{abstract}

Liu and Opdam To present a new approach for ES valuation (2014) as integral parts of community-based landscape planning processes

Kopperoinen To assess Green Infrastructure based on the et al. (2014) provision potential of ES, and to investigate how interactions with experts and local and regional actors impacts methods development

Frank et al. To develop an approach for integrating the (2014) ES concept into regional planning in Germany

Casado- $\quad$ To present a method to quantify cultural ES Arzuaga et al. and their spatial distribution in the (2014) landscape, considering both ecological structures and social evaluation approaches

Moreno et al. To explore how participative mental (2014) models can help integrating the ES framework into management

PalaciosAgundez et al. (2014)
To develop an approach that integrates scientific knowledge and stakeholders demands concerning ES to provide decision-making guidelines for sustainable landscape development
Perspective paper: proposition of the model and examples for application

Development and application of a new valuation scheme based on wellbeing

Development and application of a semiquantitative place-based method including expert participation

Using decision support software, participatory scenario development

Providing quantified, GIS-based assessments of ES based on ecological structure and social evaluation approaches, validation of maps with information from participatory processes

Development of mental models together with stakeholders in a case study

Design, conduct and evaluation of a participatory and scientific assessment and planning process n.a.

Province of SouthHolland, The Netherlands

Three watershed in southern Finland

Upper-Elbe-ValleyEastern-Ore-

Mountains,

Germany

Metropolitan Region of Bilbao, Basque

Country, Spain

National Parks of Doñana and Sierra Nevada, Andalusia, Spain

County of Biscay, Spain 
Table 1 continued

\begin{tabular}{|c|c|c|c|}
\hline Authors & Objectives & Research methods & Case study area \\
\hline \multicolumn{4}{|c|}{ Theme III: Which impacts can be expected from integrating the ES concept in policy and decision-making } \\
\hline $\begin{array}{l}\text { Fürst et al. } \\
\text { (2014) }\end{array}$ & $\begin{array}{l}\text { To develop an evaluation scheme for assessing the } \\
\text { contributions of applying the ES concept for } \\
\text { facilitating participatory planning }\end{array}$ & $\begin{array}{l}\text { Developing a balanced score } \\
\text { card tool and applying it in } \\
\text { two case studies }\end{array}$ & $\begin{array}{l}\text { HoekscheWaard, The } \\
\text { Netherlands } \\
\text { Upper-Elbe-Valley- } \\
\text { Eastern-Ore- } \\
\text { Mountains, } \\
\text { Germany }\end{array}$ \\
\hline $\begin{array}{l}\text { Hatton } \\
\text { MacDonald } \\
\text { et al. (2014) }\end{array}$ & $\begin{array}{l}\text { To investigate the accessibility and usefulness of the } \\
\text { ES framework to policy analysts }\end{array}$ & $\begin{array}{l}\text { Mixed method approach of } \\
\text { document analysis and semi- } \\
\text { structured interviews }\end{array}$ & $\begin{array}{l}\text { Murray-Darling } \\
\text { Basin, Australia }\end{array}$ \\
\hline
\end{tabular}

While the papers are allocated to the research theme of their prime focus, many of them also provide insights for other themes

and communication of ES information need to be adapted to specific context. Planners and decisionmakers in Germany, Portugal, and South Africa acknowledge that integrating the ES concept could be useful and beneficial for practice, while the level of prior knowledge varies considerably between the countries (Albert et al. 2014; Mascarenhas et al. 2014; Sitas et al. 2014). Information of the ES concept among planning practitioners stems mainly from practice-oriented information materials and personal interactions with researchers, while major ES assessments such as the MA are mostly unknown (Albert et al. 2014; Mascarenhas et al. 2014).

Applying the ES concept is considered most promising in multi-sectorial planning contexts of high policy relevance such as disaster-proof planning (Sitas et al. 2014). The perceived added value of applying the ES concept lies in communicating the contributions and values of ecosystems and biodiversity to the wellbeing of different stakeholder groups, and in highlighting the impacts of planning alternatives on these contributions. Exploiting this added value however seems to depend upon the type of environmental information and planning systems already available. Introducing the ES concept in countries with emerging planning institutions could provide greater benefits than in well-established planning systems that already consider environmental data that could be associated with ES but use different terms.

Despite the perceived usefulness of the ES concept as a device for planning communication and decisionsupport, discussions with practitioners revealed important challenges for greater application, in particular the persisting confusions and criticisms of the
ES concept and the need to provide information in the appropriate format, scale and timing for the issue at stake. Confusion persists regarding the multitude of definitions of the ES concept, ignorance surrounding its relationship to other concepts already in use by planners, the lack of practical guidelines and of case studies illustrating the actual application of the concept in planning. Major criticisms of the ES concept as mentioned by practitioners included its (perceived) focus on economic valuation, its supposed contribution to the risk of further commodification of nature, and the potential conflict or trade-off scenarios with regards to biodiversity conservation objectives (Albert et al. 2014; Sitas et al. 2014).

Multiple approaches to integrating ES in planning

Many approaches are available for integrating the ES concept in (participatory) planning with different and complementary contributions to decision-making. The broad range of methods for applying the ES concept in planning and management have been classified into four types with different procedures for participation, benefits and shortcomings (Table 2).

Responding to the need to adapt ES frameworks and categories to the specific context and issues at stake (Fisher et al. 2009), von Haaren et al. (2014) propose an ES model for planning applications that differentiates between offered and utilized ES, reflecting similar considerations by Casado-Arzuaga et al. (2014) and Kopperoinen et al. (2014).

The cognitive mapping approach suggested by Moreno et al. (2014) facilitated a collaborative process for identifying key actors, main driving forces of 
Table 2 Four types of approaches for integrating the ES concept in planning, their respective procedures for involving users and stakeholders, respective benefits and shortcomings, and exemplary contributions to this special issue

\begin{tabular}{|c|c|c|c|c|}
\hline $\begin{array}{l}\text { Types of } \\
\text { approaches for } \\
\text { integrating ES in } \\
\text { planning }\end{array}$ & $\begin{array}{l}\text { Procedures for } \\
\text { participation }\end{array}$ & Benefits & Shortcomings & $\begin{array}{l}\text { Exemplary } \\
\text { contributions }\end{array}$ \\
\hline $\begin{array}{l}\text { Specifically } \\
\text { adapted } \\
\text { conceptual } \\
\text { frameworks }\end{array}$ & $\begin{array}{l}\text { High level of knowledge } \\
\text { co-production }\end{array}$ & $\begin{array}{l}\text { Clarifies the key aspects to } \\
\text { consider and their relationships } \\
\text { Forms the basis for } \\
\text { communication and joint } \\
\text { analyses }\end{array}$ & $\begin{array}{l}\text { Deviate from } \\
\text { existing, well- } \\
\text { known general } \\
\text { frameworks may } \\
\text { cause confusion }\end{array}$ & $\begin{array}{l}\text { Von Haaren et al. } \\
\text { (2014) }\end{array}$ \\
\hline $\begin{array}{l}\text { Cognitive } \\
\text { mapping }\end{array}$ & $\begin{array}{l}\text { High level of knowledge } \\
\text { co-production throughout }\end{array}$ & $\begin{array}{l}\text { Allows exploring and } \\
\text { communicating ES providers } \\
\text { and beneficiaries, their } \\
\text { relationships, and the complex } \\
\text { interactions } \\
\text { To devise appropriate } \\
\text { governance strategies }\end{array}$ & Not spatially explicit & Moreno et al. (2014) \\
\hline $\begin{array}{l}\text { Simulations } \\
\text { supporting } \\
\text { visioning/ } \\
\text { scenario studies }\end{array}$ & $\begin{array}{l}\text { Often co-production of } \\
\text { scenario assumptions and } \\
\text { storylines, less } \\
\text { involvement in spatial } \\
\text { simulation }\end{array}$ & $\begin{array}{l}\text { Allows exploring the spatial } \\
\text { implications of management } \\
\text { options concerning land use } \\
\text { change and impacts on ES }\end{array}$ & $\begin{array}{l}\text { Actor interactions } \\
\text { difficult to consider }\end{array}$ & $\begin{array}{l}\text { Palacios-Agundez } \\
\text { et al. (2014), Frank } \\
\text { et al. (2014) }\end{array}$ \\
\hline $\begin{array}{l}\text { Combined } \\
\text { biophysical } \\
\text { modelling and } \\
\text { expert or social } \\
\text { evaluation }\end{array}$ & $\begin{array}{l}\text { Systematic involvement of } \\
\text { stakeholders, at best } \\
\text { iterative development of } \\
\text { results }\end{array}$ & $\begin{array}{l}\text { Allows validating and enhancing } \\
\text { the assessment and valuation } \\
\text { of ES } \\
\text { Enables integration of multiple } \\
\text { ES values as perceived by } \\
\text { different actor groups }\end{array}$ & $\begin{array}{l}\text { Relatively substantial } \\
\text { engagement of } \\
\text { actors required } \\
\text { Opinions of focus } \\
\text { group need to be } \\
\text { representative }\end{array}$ & $\begin{array}{l}\text { Kopperoinen et al. } \\
\text { (2014), Casado- } \\
\text { Arzuaga et al. } \\
\text { (2014), Liu and } \\
\text { Opdam (2014) }\end{array}$ \\
\hline
\end{tabular}

change, and their interactions. As such, cognitive mapping can usefully amend spatial assessments and valuation of ES by developing common understandings and to co-generating place-specific solution strategies (cf. Sitas et al. 2014).

ES approaches supporting visioning and scenario studies are a good way of producing useful information to develop public understanding, to support social learning (Albert et al. 2012), or to improve actual decision-support among alternatives. While Frank et al. (2014) show how ES assessments can explicate the trade-offs between different management scenarios, Palacios-Agundez et al. (2014) illustrate an approach to underpin a visioning exercise with spatial analyses of the vision's implications.

Combined biophysical modelling and expert or social evaluation approaches may help in implementing assessment and valuation. Kopperoinen et al. (2014) reemphasized that ES assessments and valuation could usefully start with expert-based assessments to gain first insights, and evolve into more empirically founded assessments when moving towards decisionmaking at the site level. The combined modeling and evaluation approach employed by Casado-Arzuaga et al. (2014) to investigate recreational ES results in relevant insights for planning, for instance the validation of modelling and the identification of unused recreation potentials. Finally, Liu and Opdam (2014) develop a valuation mechanism that is systematically integrated in the planning cycle to capture the multidimensional understandings of human wellbeing and values.

Involving users and stakeholders in planning processes around ES is recommended by Sitas et al. (2014) and Albert et al. (2014) due to its several benefits for decision-making. Participation may further substantial knowledge, for instance concerning interactions between biophysical and socio-economic systems, contribute to mutual learning, and reveal implications for governance (Casado-Arzuaga et al. 2014; Kopperoinen et al. 2014). However, important challenges of participation need to be acknowledged, 
including the lack of representativeness of local engagement processes, the little time that key policy makers may allocate to participation (Hatton MacDonald et al. 2014), the need for integrating different knowledge types (Liu and Opdam 2014), and often limited experience and resources for facilitating participation in planning practice (Casado-Arzuaga et al. 2014).

The lack of quantitative data is often mentioned in scientific literature as a problem in applying ES in practice. However, planning practice usually does not require the most detailed environmental information that could potentially be provided, but rather data that is considered sufficiently robust to serve as the basis for decision-making. For example, quantitative assessments are not always necessary. Instead semi-quantitative comparative approaches based on ordinal scales, have often proved sufficient (Albert et al. 2014). Gradually improving the data quality as new insights become available as suggested by Kopperoinen et al. (2014) helps overcoming the frequent paucity of existing data and lack of resources for empirical analyses.

Scoping, implementation, and assessment of planning for ES

Effectively integrating the ES concept in planning requires careful scoping of the context, objectives, and capacities, and to appropriately design and implement the planning, ES assessment and valuation processes. Integrating the ES concept in planning depends on the existing governmental planning instruments. In planning systems with rigid planning systems, formally mainstreaming the ES concept requires a political mandate, active support, and patience. In planning cultures with more active roles of stakeholders, implementing the ES concept may have many more opportunities. In all cases, however, decision-making for integrating the ES concept and for stronger considering ES information in planning and decision-making is challenged due to the required changes in the actors' personal frames of reference linked with underlying beliefs and values. To this end, information on ES alone is not sufficient, but needs to contribute to social learning, negotiation and the development of common meaning and visions. Targeting the people and institutions that are most influential in steering landscape development at local level seems particularly promising for facilitating main streaming (Sitas et al. 2014).
The several challenges of integrating the ES concept in planning point to the need for an initial process of careful scoping together with potential users, stakeholders and scientists to ensure political relevance and legitimacy (Albert et al. 2014; Sitas et al. 2014). The objectives of such scoping would be to identify the needs and interests of potential users, to clarify the specific planning instruments and decisionmaking processes in which the ES concept should be applied, and to estimate the scientific capacities and resources available (cf. Palacios-Agundez et al. 2014).

The subsequent design of the planning and implementation process, as well as the integrated ES assessment and valuation processes, need to be responsive to the identified context, objectives, and requirements. While planning based on ES assessments can theoretically achieve various objectives ranging from general public information to site-level decision support, they usually cannot be achieved simultaneously as each objective requires specific implementation approaches. A problem-specific combination of approaches for integrating the ES concept in planning should be chosen that is most likely to usefully address the identified research questions in the specific decision-context. The choice of methods should also consider the available data, temporal and financial resources, the required information formats, and most importantly, the spatial and temporal scale at which the information shall be used (Hatton MacDonald et al. 2014). Furthermore, the emerging critiques of the ES concept among scientists and practitioners (e.g. Schröter et al. 2014; von Haaren et al. 2014) need to be acknowledged and carefully addressed.

The implementation of planning processes with the ES concept should be conducted as a reflexive process, responding to emerging challenges and opportunities for science-practice collaboration. The relevance of the aspired planning results for decision-making should be critically evaluated throughout the planning process and after its completion in order to learn and adapt (future) planning processes accordingly.

Facilitation for decision-making and collaborative planning

Integrating the ES concept in planning provides new and useful information to support decision-making and may facilitate collaborative planning and 
implementation of diverse actors. The inclusion of the ES concept in planning institutions and decisions yields additional and hitherto unavailable information, e.g. on a broader range of ES, the actual use of and demand for ES, their contributions to human wellbeing, associated values, potential trade-offs between planning alternatives, and concerning quantitative benchmarks and development objectives (von Haaren et al. 2014). In the Finish case study, planners acknowledge the potential of the ES concept to promote discussions of the relevance of green spaces and in highlighting the services they produce (Kopperoinen et al. 2014). In the case study on planning for recreational ES in the Basque County, local administrators perceived the information on ES as relevant and now intent to include them in planning decisions (Casado-Arzuaga et al. 2014). Frank et al. (2014) reported that their ES assessment results were taken up by the planning authority in the revision of the regional plan and supported the introduction of strict and binding targets for erosion protection. Hatton MacDonald et al. (2014) even found evidence that the generated ES information actually influenced realworld decision-making.

Besides the provision of new and useful knowledge, applying the ES concept may also have several benefits for facilitating cooperative planning and implementation. In the Australian case study, the ES framework proved useful as a tool for communication both between scientists and with others (Hatton MacDonald et al. 2014). Fürst et al. (2014) summarize the evidence for the potentially beneficial impact of using ES in collaborative landscape planning. They emphasize the need for systematically monitoring this impact in planning practice to create a shared reference for learning and making improvements in approaches and tools, and they propose a simple learning tool that can be used in a wide range of planning cases.

\section{Concluding remarks}

This special issue opens up a new research field of 'Planning-for-ES Science' in the rapidly evolving stream of ES studies. This field should be developed rapidly in order to ensure that the added value of the ES concept contributes fully to landscape planning and management. In particular, future research on Planning for ES could aim at
- developing indication systems adapted to specific contexts of ES application in planning, including appropriate ES frameworks, sets of ES to consider, indicators to use, and assessment and valuation procedures to employ

- suggesting improved methods for assessing and valuing ES, especially for rarely investigated ES and concerning contributions to human wellbeing, which are flexible to variable planning contexts and allow the evolution of value perception during the planning process (for example by using social media)

- creating place-specific planning and implementation strategies that contribute to sustainable landscape development through simultaneously attaining societal objectives, maintaining biodiversity, and delivering important ES

- exploring how the ES concept could be employed as a boundary object to facilitate knowledge coproduction and cooperation between different actors

- learning from planning experiments and empirical case study applications and to formulate recommendations how ES could be applied in selected planning instruments and decisions in ways most likely to enhance knowledge, facilitate cooperation, and impact decision-making

Acknowledgments This special issue is the collaborative output of the Ecosystem Services Partnership (ESP) Thematic Working Group "ES in Planning and Management". It benefitted from discussions in an ESP workshop in Kiel, Germany, and the ESP conference in Tanah Lot, Bali, in 2013. We thank the session co-organizers, Jennifer Hauck and Francis Turkelboom, the meetings organizers (in particular, Benjamin Burkhard, Robert Costanza, Rudolf de Groot, Felix Müller, and Meine van Noordwijk), and the many participants for their support. We are grateful for the many reviewers who helped in improving the manuscripts. Thanks also to Jianguo $\mathrm{Wu}$ for a review of this paper. Most importantly, we thank our authors for their interest and patience to contribute their work. C.A. acknowledges funding by Leibniz Universität Hannover for the QUANTIFY project.

\section{References}

Albert C, Zimmermann T, Knieling J, von Haaren C (2012) Social learning can benefit decision-making in landscape planning: Gartow case study on climate change adaptation, Elbe valley biosphere reserve. Landscape Urban Plan 105(4):347-360

Albert C, Hauck J, Buhr N, von Haaren C (2014) What ecosystem services information do users want? Investigating 
interests and requirements among landscape and regional planners in Germany. Landscape Ecol. doi:10.1007/ s10980-014-9990-5

Alkemade R, Burkhard B, Crossman ND, Nedkov S, Petz K (2014) Quantifying ecosystem services and indicators for science, policy and practice. Ecol Indic 37(Part A(0)):161-162

Bastian O, Grunewald K, Syrbe R-U, Walz U, Wende W (2014) Landscape services: the concept and its practical relevance. Landscape Ecol 10:1-17

Bateman IJ, Harwood AR, Mace GM, Watson RT, Abson DJ, Andrews B, Binner A, Crowe A, Day BH, Dugdale S, Fezzi C, Foden J, Hadley D, Haines-Young R, Hulme M, Kontoleon A, Lovett AA, Munday P, Pascual U, Paterson J, Perino G, Sen A, Siriwardena G, van Soest D, Termansen M (2013) Bringing ecosystem services into economic decision-making: land use in the United Kingdom. Science 341(6141):45-50

Burkhard B, de Groot R, Costanza R, Seppelt R, Jørgensen SE, Potschin M (2012) Solutions for sustaining natural capital and ecosystem services. Ecol Ind 21:1-6

Casado-Arzuaga I, Onaindia M, Madariaga I, Verburg P (2014) Mapping recreation and aesthetic value of ecosystems in the Bilbao Metropolitan Greenbelt (Northern Spain) to support landscape planning. Landscape Ecol. doi:10.1007/ s10980-013-9945-2

Cowling RM, Egoh B, Knight AT, O'Farrell PJ, Reyers B, Rouget M, Roux DJ, Welz A, Wilhelm-Rechman A (2008) An operational model for mainstreaming ecosystem services for implementation. Proc Natl Acad Sci 105(28):9483

Daily GC, Polasky S, Goldstein J, Kareiva PM, Mooney HA, Pejchar L, Ricketts TH, Salzman J, Shallenberger R (2009) Ecosystem services in decision making: time to deliver. Front Ecol Environ 7(1):21-28

de Groot RS, Alkemade R, Braat L, Hein L, Willemen L (2010) Challenges in integrating the concept of ecosystem services and values in landscape planning, management and decision making. Ecol Complex 7(3):260-272

Fisher B, Turner RK, Morling P (2009) Defining and classifying ecosystem services for decision making. Ecol Econ 68(3):643-653

Frank S, Fürst C, Witt A, Koschke L, Makeschin F (2014) Making use of the ecosystem services concept in regional planning - trade-offs from reducing water erosion. Landscape Ecol. doi:10.1007/s10980-014-9992-3

Fürst C, Opdam P, Inostroza L (2014) Learning about the role of ecosystem services in participatory land use planning: proposing a balanced score card. Landscape Ecology 42:10-19

Geneletti D (2013) Ecosystem services in environmental impact assessment and strategic environmental assessment. Environ Impact Assess Rev 40:1-2

Haase D, Frantzeskaki N, Elmqvist T (2014) Ecosystem Services in Urban Landscapes: practical Applications and Governance Implications. Ambio 43(4):407-412

Hatton MacDonald D, Bark R, Coggan A (2014) Is ecosystem service research used by decision-makers? A case study of the Murray-Darling Basin, Australia. Landscape Ecol. doi:10.1007/s10980-014-0021-3

Hauck J, Schweppe-Kraft B, Albert C, Görg C, Jax K, Jensen R, Fürst C, Maes J, Ring I, Hönigová I, Burkhard B, Mehring M, Tiefenbach M, Grunewald K, Schwarzer M, Meurer J,
Sommerhäuser M, Priess JA, Schmidt J, Grêt-Regamey A (2013) The promise of the ecosystem services concept for planning and decision-making. GAIA - Ecol Perspect Sci Soc 22(4):232-236

Hubacek K, Kronenberg J (2013) Synthesizing different perspectives on the value of urban ecosystem services. Landscape Urban Plan 109(1):1-6

Iverson L, Echeverria C, Nahuelhual L, Luque S (2014) Ecosystem services in changing landscapes: an introduction. Landscape Ecol 29(2):181-186

Kopperoinen L, Itkonen P, Niemelä J (2014) Using expert knowledge in combining green infrastructure and ecosystem services in land use planning: an insight into a new place-based methodology. Landscape Ecol. doi:10.1007/ s10980-014-0014-2

Liu J, Opdam P (2014) Valuing ecosystem services in community-based landscape planning: introducing a wellbeing-based approach. Landscape Ecol. doi:10.1007/s10980014-0045-8

Mascarenhas A, Ramos T, Haase D, Santos R (2014) Integration of ecosystem services in spatial planning: a survey on regional planners' views. Landscape Ecol. doi:10.1007/ s10980-014-0012-4

Moreno J, Palomo I, Escalera J, Martin-Lopez B, Montes C (2014) Incoporating ecosystem services into ecosystembased management to deal with complexity: a participative mental model approach. Landscape Ecol. doi:10.1007/ s10980-014-0053-8

Musacchio LR (2013) Key concepts and research priorities for landscape sustainability. Landscape Ecol 28(6):995-998

Opdam P, Nassauer J, Wang Z, Albert C, Bentrup G, Castella J-C, McAlpine C, Liu J, Sheppard S, Swaffield S (2013) Science for action at the local landscape scale. Landscape Ecol 28(8):1439-1445

Palacios-Agundez I, Fernández de Manuel B, Rodríguez-Loinaz G, Peña L, Ametzaga-Arregi I, Alday J, Casado-Arzuaga I, Madariaga I, Arana X, Onaindia M (2014) Integrating stakeholders' demands and scientific knowledge on ecosystem services in landscape planning. Landscape Ecol. doi:10.1007/s10980-014-9994-1

Potschin MB, Haines-Young RH (2011) Ecosystem services: exploring a geographical perspective. Prog Phys Geogr 35(5):575-594

Primmer E, Furman E (2012) Operationalising ecosystem service approaches for governance: do measuring, mapping and valuing integrate sector-specific knowledge systems? Ecosyst Serv 1(1):85-92

Schröter M, van der Zanden EH, van Oudenhoven APE, Remme RP, Serna-Chavez HM, de Groot RS, Opdam P (2014) Ecosystem services as a contested concept: a synthesis of critique and counter-arguments. Conserv Lett. doi:10. 1111/conl.12091

Sitas N, Prozesky H, Esler K, Reyers B (2014) Opportunities and challenges for mainstreaming ecosystem services in development planning: perspectives from a landscape level. Landscape Ecol. doi:10.1007/s10980-013-9952-3

Termorshuizen J, Opdam P (2009) Landscape services as a bridge between landscape ecology and sustainable development. Landscape Ecol 24(8):1037-1052

van Oudenhoven APE, Petz K, Alkemade R, Hein L, de Groot RS (2012) Framework for systematic indicator selection to 
assess effects of land management on ecosystem services. Ecol Ind 21:110-122

von Haaren C, Albert C (2011) Integrating ecosystem services and environmental planning: limitations and synergies. Int J Biodivers Sci Ecosyst Serv Manag 7(3):150-167

von Haaren C, Albert C, Barkmann J, De Groot RS, SchröterSchlaack C, Hansjürgens B (2014) From Explanation to
Application: Introducing a Practice-Oriented Ecosystem Services Evaluation (PRESET) Model Adapted to the Context of Landscape Planning and Management. Landscape Ecol. doi:10.1007/s10980-014-0084-1

Wu J (2013) Landscape sustainability science: ecosystem services and human well-being in changing landscapes. Landscape Ecol 28(6):999-1023 